\title{
Suomalaisen Kirjallisuuden Seuran 180o-luvulla kustantamat vieraskieliset sanakirjat: funktiot, odotukset ja vastaanotto
}

\section{Johdanto}

Suomalaisen kulttuuritietouden kasvattaminen, suomenkielisen kirjallisuuden tuottaminen ja suomen kehittäminen sivistyskieleksi ovat kuuluneet Suomalaisen Kirjallisuuden Seuran (SKS) keskeisimpiin tavoitteisiin sen perustamisvuodesta 1831 lähtien. Varsinaista kustannustoimintaa SKS on harjoittanut vuodesta 1834, ja aivan alkuvuosikymmenistä lähtien erilaiset sanakirjahankkeet ovat olleet huomattava osa sen toimintaa. SKS onkin ollut merkittävä suomen joko lähtö- tai kohdekielenä sisältävien vieraskielisten sanakirjojen sekä erityyppisten kansallisten sanakirjojen kustantaja. Erityisesti 180o-luku oli SKS:n sanakirjojen julkaisutoiminnan kulta-aikaa. Myös muut toimijat, kuten Gummerus, G. W. Edlund, K. E. Holm ja WSOY, kustansivat sanakirjoja 180o-luvulla; laajinta ja ohjelmallisinta toiminta oli kuitenkin SKS:lla. ${ }^{1}$

Tässä artikkelissa syvennymme tarkastelemaan SKS:n 1800-luvulla kustantamia vieraskielisiä sanakirjoja, niiden kustantamiseen liittyviä tavoitteita, niihin kohdistuneita odotuksia ja niiden vastaanottoa. Lähestymme tutkimuskohdettamme kustantajan, sanakirjan laatijan ja julkaisun vastaanottajan näkökulmista. Näiden kolmen tahon ääniä tutkimuksessamme edustavat SKS:n kokouspöytäkirjat, julkaistujen sanakirjojen esipuheet ja teoksista kirjoitetut arviot. Vieraskielisillä sanakirjoilla viittaamme tutkimuksessamme teoksiin, joissa toisena kielenä on suomi ja toisena jokin muu kieli kuin ruotsi. 1800-luvun

1 SKS:n 180o-luvun julkaisutoimintaa on selvitetty useissa yhteyksissä (esim. Krohn 1931; Haltsonen 1931; Sulkunen 2004; Häggman 2011; yleisesti 1800-luvun kustannustoiminnasta ks. Häggman 2008; myös Kovala 2013; Paloposki 2013). Suomen toisena kielenä sisältäviä sanakirjoja julkaistiin 180o-luvulla myös ulkomailla. Keskeisiä motiiveja olivat virinnyt etäsukukieliharrastus sekä ulkomaille suunnanneet suomalaiset siirtolaiset, joita varten julkaistiin ennen kaikkea englanninkielisiä sanastoja (ks. Koukkunen 2012; myös 2014). 
varhaiset vieraskieliset sanakirjat ovat kielentutkimuksen ja oppihistorian osa-alueena jääneet pitkälti katveeseen. ${ }^{2}$

\section{Tutkimusaineiston rajaus ja esittely}

SKS julkaisi 180o-luvun kuluessa erityyppisiä sanakirjoja ja muita sanastoja. Olemme valinneet näistä tutkimuskohteeksi aihepiiriltään rajaamattomat ja laajat yleissanakirjat, jotka on tarkoitettu niin kouluopetuksen kuin muiden sanakirjaa tarvitsevien käyttöön. Olemme rajanneet tarkastelun ulkopuolelle SKS:n 180o-luvulla julkaisemat kieliparin suomi-ruotsi sanakirjat, muutamat tietyn aihepiirin sanastoa kuvaavat erikoissanakirjat sekä koululukemistojen yhteydessä julkaistut sanastot. ${ }^{3}$ Tarkasteltavien 1800 -luvun vieraskielisten yleissanakirjojen toimitusperiaatteet ja tavoitteet ovat siinä määrin yhtenevät, että voidaan puhua samaa genreä edustavista teoksista. Tutkimuskohteena olevat sanakirjat painoksineen on lueteltu taulukossa 1.

Varhaisin tarkasteltavista teoksista on vuonna 1864 julkaistu Frans Wilhelm Rothstenin Latinais-suomalainen sanakirja koulujen tarpeeksi. Sitä seurasi SKS:n kustantamana kaksi muuta suomi kohdekielenä -sanakirjaa: Bernhard Fredrik Godenhjelmin Saksalaissuomalainen sanakirja (1873) ja Agathon Meurmanin Ranskalais-suomalainen sanakirja (1877). Tämän jälkeen julkaistiin ensimmäiset suomi lähtökielenä -sanakirjat, Johan Gabriel Geitlinin Suomalais-latinainen sanakirja (1883) ja Karl Ervastin Suomalais-saksalainen sanakirja (1888). Niitä seurasi neljäs suomi kohdekielenä -teos, Agathon Meurmanin Venäläis-suomalainen sanakirja (1895). Tarkasteltavan ajanjakson päättää Eino Sakari Yrjö-Koskisen Suomalais-ranskalainen sanakirja (1900). Vain muutamasta teoksesta otettiin uusintapainos, mikä kertoo sanaston nopeasta kasvusta ja teosten nopeasta vanhenemisesta. Käytännössä uuden hankkeen toteuttajaksi ryhtyi aina uusi henkilö.

Varsinainen tutkimusaineisto koostuu kolmeen tekstilajiin perustuvista osa-aineistoista. Tutkimuksessa analysoidaan tarkasteltaviin teksteihin ja niiden väliseen vuoropuheluun kirjoittuneita odotuksia ja näkemyksiä. Ensimmäinen osa-aineisto muodostuu SKS:n yleiskokouksista vuosina 1860-1901 laadituista pöytäkirjoista. Pöytäkirjat julkaistiin vuodesta 1858 lähtien seuran toimittamassa Suomi-sarjassa niin kutsuttuina keskustelemuksina (esim. Sulkunen 2004, 92); ne ovat pääosin luettavissa myös Kansalliskirjaston digitoiduissa aineistoissa. Kokouspöytäkirjat ovat SKS:n toimintaa kuvaavia asiakirjoja, jotka avaavat seuran kustannustoimintaa, tavoitteita ja näkemyksiä monin tavoin. Pöytäkirjoihin tallennettiin paitsi kokouksissa käsitellyt aiheet myös esimiehen puheet ja liitteinä muun muassa toimikuntien laatimat lausunnot. Tässä kustantajatahon puheenvuorossa äänensä saavat kuuluviin ennen kaikkea seuran keskeiset toimijat. Sisällöltään

2 Artikkelimme on jatkoa aiemmalle tutkimuksellemme, jossa tarkastelemme yhteen SKS:n kustantamaan sanakirjaan liitettyjä tavoitteita ja niiden toteuttamista (Nummila-Seppänen 2018).

3 SKS:n julkaisuista yleisesti ks. Sulkunen 2004, 302-305; kieliparin suomi-ruotsi sanakirjoista ks. Romppanen 2001. 
Taulukko 1. SKS:n 180o-luvulla kustantamat vieraskieliset sanakirjat.

\begin{tabular}{|l|l|l|l|}
\hline vuosi & sanakirja & laatija & painokset \\
\hline 1864 & $\begin{array}{l}\text { Latinais-suomalainen sanakirja koulujen } \\
\text { tarpeeksi }\end{array}$ & F. W. Rothsten & 2.p. 1884 \\
\hline 1873 & Saksalais-suomalainen sanakirja & B. F. Godenhjelm & 2. p. I 1906, II 1916 \\
\hline 1877 & Ranskalais-suomalainen sanakirja & A. Meurman & \\
\hline 1883 & Suomalais-latinainen sanakirja & J. G. Geitlin & [näköisp. 1996] \\
\hline 1888 & Suomalais-saksalainen sanakirja & K. Ervast & \\
\hline 1895 & Venäläis-suomalainen sanakirja & A. Meurman & \\
\hline 1900 & Suomalais-ranskalainen sanakirja & E. S. Yrjö-Koskinen & \\
\hline
\end{tabular}

ja peruspiirteiltään SKS:n 180o-luvun pöytäkirjat vastaavat nykyisiä tieteellisten seurojen pöytäkirjoja, vaikka ne ovatkin toisinaan melko yksityiskohtaisia dokumentteja. Käytännössä pöytäkirjaa pitävä sihteeri joutui kiteyttämään käydyistä keskusteluista olennaisen ja tekemään valintoja siitä, mitä kirjataan muistiin. Tosin sihteeri saattoi saada pöytäkirjoissa myös oman äänensä kuuluviin (ks. esim. Häggman 2011, 37-38). Joka tapauksessa pöytäkirjat ovat merkittävimpiä SKS:n historiasta kertovia dokumentteja.

Toisen osa-aineiston muodostavat edellä esiteltyjen sanakirjojen esipuheet. Ne ovat tekstilajina sidonnaisia, toisten tekstien yhteydessä esiintyviä ja niiden lukemiseen ja ymmärtämiseen ohjaavia, tekstejä. Esipuheessa sanakirjan laatija tyypillisesti valottaa keskeisiä teoksen laatimiseen liittyviä olosuhteita kuten tehtävään ryhtymisen syitä, omaa kompetenssiaan, käyttämiään lähteitä ja kustantajan roolia prosessissa. Esipuhe on kirjoittajan puheenvuoro, josta välittyvät hänen henkilökohtaiset näkemyksensä ja käsityksensä toimintaperiaatteista, joiden varassa tai joiden mukaan hän on toiminut teosta koostaessaan. Kysymys on vuorovaikutustilanteesta, jonka tyypillisiä funktioita ovat informaation välittäminen, vaikuttaminen ja yhteyden luominen vastaanottajaan (esim. Kääntä 2005; ks. 1800-luvun esipuhekäytänteistä myös Szalai 2006). Toisin kuin monissa muissa julkaisutyypeissä sanakirjassa esipuhe on käytännössä ainoa paikka, jossa kirjoittaja saa oman äänensä kuuluviin ja mielipiteensä eksplisiittisesti esiin. Tarkasteltaviin sanakirjoihin on yhtä (Meurman 1877) lukuun ottamatta kirjoitettu esipuheteksti.

Tutkimuksen kolmas osa-aineisto käsittää tarkasteltavista sanakirjoista kirjoitetut arviot. Suomalaisessa lehdistössä kirja-arviot kehittyivät omaksi tekstilajikseen $1800-$ luvun kuluessa. Niitä julkaistiin ahkerasti, ja kaikki vähänkin merkittävät painotuotteet pyrittiin arvioimaan (Häkkinen 2008, 183; ks. toiminnasta Paloposki-Riikonen 2013, 599-608; 1800-luvun kirjallisuuskritiikistä myös Paloposki 2007; Riikonen 2007; Jantunen 2011). Arvion keskeisiä funktioita ovat teoksen esitteleminen, teoksen paikantaminen kirjalliselle kentälle, kritiikin esittäminen ja teoksen kirjallista ja käytännöllistä arvoa koskevan valistuneen näkemyksen tarjoaminen lukijalle. Arviot olivat erityisesti 1800luvun alkupuolella kannustavia ja kiittäviä, koska varhaista suomenkielistä kirjallisuutta haluttiin tukea kaikin tavoin. Käsittely muuttui ajan kuluessa yksityiskohtaisemmaksi 
ja erityisesti kieliasiat nousivat keskeisiksi teemoiksi. (Paloposki-Riikonen 2013, 600.) 180o-luvun kirja-arviot ovat tyypillisesti suorapuheisia, ja lehdissä käytiin myös henkilökohtaisuuksiin meneviä riitoja (Häkkinen 2008, 183; ks. myös Koukkunen 2004). Vuorovaikutuksen näkökulmasta arvio on teoksen vastaanottajan eli lukijakunnan puheenvuoro. Ennen kaikkea se on kuitenkin vertaisarvio, jonka laatijana toimi tyypillisesti alan asiantuntija. Tutkimusaineisto koostuu kieli- ja kulttuuriaiheita käsittelevissä julkaisuissa ilmestyneistä asiantuntija-arvioista. Erityisen merkittäviä arvioiden julkaisijoita olivat Kirjallinen Kuukauslehti ja Valvoja (ks. julkaisujen ja arvioijien neutraaliudesta luku 6).

\section{SKS 180o-luvun sanakirjojen kustantajana: yleisiä tavoitteita ja toimintamalleja}

Kuten mainittua, sanakirjojen kustantaminen kuului SKS:n ohjelmaan alkuvuosikymmeniltä lähtien ja toiminnan merkittävin vaihe osuu tutkimuksessa tarkasteltavalle ajanjaksolle. 180o-luvulla seuralla oli kaikkiaan tärkeä asema suomalaisen kirjallisuuden kustantajana ja esikuvallinen rooli kirjoitetun suomen kielen käytössä ja kehittämisessä (esim. Häkkinen 2008, 183). Sanakirjojen julkaiseminen ei ollut taloudellisesti kannattavaa (ks. esim. 1.1.1878 Suomi 12, 85), mutta kyse oli kansakunnan sivistyksen ja suomen kielen kehittämisen kannalta arvokkaasta työstä, jossa SKS halusi olla keskeinen toimija ja vaikuttaja. Vuoden 1872 vuosikertomuksessa vakuutetaan seuran tahtoa juhlavasti:

Näissä tämmöisissä ja muissakin kirjallisissa askareissamme on Seuran asema omituinen siinä kohden, että Seura tavallansa on vaadittu hoimiinsa ottamaan kaikkia teoksia, jotka kelvollisuutensa tähden taikka vallitsevan puutteen vuoksi välttämättömästi ovat julki saatavat, mutta joita yksityiset ei rohkene taikka ei jaksa kustantaa, koska ne ovat laveat, runsasmaksoiset ja hitaat jälleen rahoiksi muuttumaan. Juuri semmosten kirjatuottetten painattamisella on Seura epäilemättä täyttänyt ja täyttää vastakin tärkeimmän tehtävänsä. Kukapa muu niitä meillä julkaisisi? Kun ajat synkistyvät, kun mahtavain mielet nurjenevat ja vastukset enenevät, silloin on lohdutusta ja toivon aihetta siinäkin tiedossa, että kansallisella kirjallisuudella on Suomalaisen Kirjallisuuden Seurassa kumminkin jokin tuki ja turva. (1.1.1878 Suomi 12,84.)

Sanakirjatyöstä ei katsota olevan tinkimistä, koska seura edistää "kansallisuuden, järjen ja ajanhengen asiaa" ja haluaa epäilemättä säilyttää auktoriteetin ja normittajan roolin suomen kieltä koskevissa asioissa. ${ }^{4}$ Luottamus siihen, että "suomalaisuus varttuu samassa määrässä kuin sivistys, oikeuden tunto ja valtiollinen äly versovat", varmistaa työn jatkuvuuden. (1.1.1878 Suomi 12, 217.)

4 Tarkasteltavalle ajanjaksolle osuvat SKS:n ja yliopiston suomen kielen oppituolin väliset oikeakielisyysasioihin liittyvät ristiriidat. Kilpailuasetelma muodostui käytännössä August Ahlqvistin riitaannuttua SKS:n kanssa. (Ks. esim. Häkkinen 1994, 506-507; Sulkunen 2004, 141-154; ks. myös Häggman 2008, 199; 2011, 61.) 
Sanakirjojen kustantaminen vei huomattavasti resursseja jo siksi, että projektit venyivät pitkäaikaisiksi. Kokouspöytäkirjojen ja esipuheiden perusteella kysymys oli hankkeista, jotka kestivät noin neljästä seitsemääntoista vuotta. SKS sai valtiolta tukea yleishyödyllisten kirjojen painattamiseen ja vuodesta 1878 lähtien säännöllistä valtionapua (Sulkunen 2004, 179), mutta käytännössä toiminta lepäsi pitkälti lahjoitusten ja testamentattujen varojen varassa. Vaikka kustannustoiminnassa rahoitus on keskeinen asia, lähestyttiin seurassa sanakirjahankkeita ensisijaisesti muista näkökulmista. Julkaisupäätöksiä tehtäessä painoikin enemmän teoksen hyödyllisyys ja kansallinen arvo kuin se, onko seuran tilillä vaadittava määrä rahaa (Krohn 1931, 32, 42-43). Sanakirjojen julkaisemisen motiivit näkyvät selvästi vuoden 1877 vuosikertomuksessa. Siinä esimies Yrjö Sakari Yrjö-Koskinen silmää tyytyväisenä kuluneisiin vuosikymmeniin, joiden aikana suomen kielestä on tullut "korkeamman sivistyksen kannattaja", sitä on tutkittu, sanavaroja ja kansanrunoutta kerätty ja sen yhteyttä eurooppalaiseen kulttuuriin on tuettu sanakirjoja ja kielioppeja laatimalla. Sanakirjojen tarkoitus on liittää maan sivistys sekä muinaisiin että nykyisiin sivistyskieliin ja erityisesti laventaa suomenkielisten mahdollisuuksia tutustua näillä kielillä kirjoitettuun kirjallisuuteen. (1.1.1879 Suomi 13, 284.)

SKS edusti tarkasteltavana ajankohtana merkittävää kielenkäytön esikuvaa, joka vaikutti ennen kaikkea julkaisemiensa teosten kautta (esim. Häkkinen 2008, 183; ks. myös Vaittinen 2010). Seura nosti kustantamiensa teosten kieliasusta huolehtimisen merkittäväksi osaksi toimintaansa perustamalla asiantuntijaryhmiä, joiden tehtäviin kuului teosten oikeakielisyysasioiden käsittely. Näistä ensimmäisen eli yleisen tutkijakunnan tehtävänä oli tarkastaa seuralle julkaistavaksi tarjotut käsikirjoitukset, laatia niistä lausunnot ja suositella kustannettavaksi sopivia teoksia. Lausunnon yhteydessä tutkijakunta antoi kieliasua koskevan, usein varsin yksityiskohtaisen, selvityksen. Kiivaassa kehitysvaiheessa oleva kirjakieli tarjosikin runsaasti keskustelunaiheita, ja kieliasiat olivat keskeisesti esillä SKS:n toiminnassa erityisesti $1800-$ luvun jälkimmäisellä puoliskolla. Tästä kertoo myös kielitieteellisen osakunnan perustaminen vuonna 1868. Asiantuntijaryhmän tehtäviä oli suomen kielen rakenteellisen tuntemuksen lisääminen ja kielen käytön kysymysten selvittäminen. Kustannustoiminnan näkökulmasta merkittävin kielitieteelliselle osakunnalle siirtynyt tehtävä oli lausuntojen kirjoittaminen ehdotetuista käsikirjoituksista sekä kirjoittajien ohjeistaminen. (Esim. Krohn 1931, 32; Niinivaara 1931, 14-15, 19, 42-43; ks. myös Sulkunen 2004, 152-153.)

SKS:n yleisinä suomi lähtökielenä -sanakirjojen toimitusperiaatteina voidaan pitää tutkijakunnan vuonna 1865 kannanotossaan esittämiä huomioita, jotka liittyvät suunnitteilla olevaa Elias Lönnrotin suursanakirjaa (1866-1880) suppeamman ja käytännöllisemmän suomalais-ruotsalaisen sanakirjan laatimiseen. Suomen kirjakielen nuoren iän vuoksi tutkijakunta piti hyvänä suomalaissanaston toimittamispolitiikkana ennemmin rajauksen väljyyttä kuin tiukkuutta: kirjakieli on vasta "poimimassa kansan suusta" tarpeellisia ilmaisuja käyttöönsä. Tämän vuoksi kirja- ja puhekieli eivät saisi vielä liiaksi rajautua. Ilmaisuja ei tulisi myöskään merkitä sanakirjaan murteellisiksi, koska tällainen väistämättä mielivaltainen menettely saattaisi estää "kirjakielen vapaata edistymistä". 
(1.1.1866 Suomi 5, 294-296.) Ainakin suomalais-ruotsalaisen sanakirjan osalta tällaista vaikutusta pidettiin siis realistisena uhkana. Tutkijakunnan sanaston koostamista koskeva yleinen neuvo kuuluu: "pää-ohjeena olkoon toimittajan järki ja taito". Ohjenuoran ilmeinen tulkinnanvaraisuus palauttaa vastuun viime kädessä kustantajalle, joka valitsee sanakirjan laatijan.

Tutkijakunnan lausunnossa nostetaan esille myös merkittävä suomenkielinen kirjallisuus, jota sanakirjan sanaston avulla tulisi pystyä lukemaan (1.1.1866 Suomi 5, 295-296). Tällä ei voida vielä vuonna 1865 viitata kovinkaan monen lyyrikon tai näytelmäkirjailijan tuotantoon; kysymys onkin ennen muuta kansanrunoudesta. Sama ajatus toistuu useissa myöhemmissä sanakirjahankkeissa: ei-suomenkielisten käyttäjien katsotaan olevan kiinnostuneita ennen kaikkea Kalevalasta. Kansanrunouden sanastosta ja myös Lönnrotin sanakirjan esikuvallisesta roolista muodostui sanakirjantekijöille painolastia, jonka vaikutus näkyy lähinnä negatiivisesti siinä, millaiseksi teosten suomalaissanasto rakentui (ks. myös Nummila-Seppänen 2018).

Tutkijakunta pyrki ohjeistamaan myös sanaston rajaamisessa: se kehottaa kannanotossaan tarpeettomien johdosten poisjättämiseen (1.1.1866 Suomi 5, 295). Tässä tehdäänkin selvä ero Lönnrotin sanakirjan toimitusperiaatteisiin, joihin kuului runsas johdosten esittely. Yleisesti voidaan todeta, että vaikka suomalaissanaston kartuttaminen sivistyskielen tasolle oli yksi tärkeimmistä 1800-luvun kirjallisen toiminnan tavoitteista ja siten myös keskeistä SKS:n työsarkaa, ei aktiivinen sanaston kehittämistyö nouse erityiseksi vieraskielisten yleissanakirjojen tehtäväksi. Keskiössä on olemassa olevan sanaston valjastaminen kirjakieliseen käyttöön, ei uuden aineksen sepittäminen. Tutkijakunnan ohjeissa huomioidaan myös käyttäjä: sanakirjan keskeiset laatimisperiaatteet ohjeistetaan kertomaan lukijalle selkeästi teoksen esipuheessa (1.1.1866 Suomi 5, 296). Näin myös yksi esipuheen keskeisistä funktioista tulee eksplikoiduksi.

Sanakirjatyö säilytti SKS:ssa keskeisen aseman vuosikymmenien ajan. 1880-luvun lopulle tultaessa alettiin kuitenkin kiinnittää huomiota siihen, että tieteellisyyden sijaan seuran julkaisutoiminta oli yleisesti ottaen ollut lähinnä käytännöllistä. Vuosikokouksessa 1887 esimies Yrjö-Koskinen viittaa tässä tarkoituksessa lukuisiin, sinänsä ansiokkaisiin, sanakirjahankkeisiin. Seura pyrki samaten irtautumaan oppikirjatuotannosta, koska se ei kuulunut sen varsinaisiin ydintoimintoihin. Varsinaiseksi tavoitteeksi haluttiin jatkossa asettaa entistä vahvemmin kansalliskirjallisuuden synnyttäminen; tähtäimessä oli suomalaisen kirjallisuuden aetas aurea, kultakausi. (1.1.1887 Suomi 20, 422-423. $)^{5}$ Käytännössä seura halusi siirtyä tavoitteissaan eteenpäin.

SKS:n 180o-luvun vieraskielisten sanakirjojen kustannustoiminta vastaa mielenkiintoisella tavalla SKS:n pitkäaikaisen sihteerin sekä tutkijakunnan ja kielitieteellisen osakunnan jäsenen F. W. Rothstenin (1833-1900) toimintakautta seurassa. Kielitaitoinen ja

5 Sekä oppi- että sanakirjatuotanto ovat olleet myös omiaan synnyttämään kansalliskirjallisuutta: monipuolinen sanavarasto, jota omakielinen oppimateriaali tukee, kehittää myös kirjallisia kykyjä. Tähän kiinnittivät huomiota niin sanakirjojen laatijat kuin arvioijat (ks. alla). 
tarkka Rothsten toimi julkaisutöiden valvojana ja paneutui sanakirjahankkeiden käynnistämiseen, suunnitteluun ja töiden tarkastukseen monin tavoin (esim. Niinivaara 1931, 50). Sanakirjojen julkaisemiseen liittyvät yleisen tutkijakunnan lausunnot olivat tyypillisesti Rothstenin käsialaa; hän oli myös kielitieteellisen osakunnan pitkäaikaisin jäsen ja siten yksi sen vaikutusvaltaisimmista toimijoista. Sihteerin tehtävässä Rothsten toimi vuodesta 1870 lähtien aina kuolemaansa asti vuoteen 1900. Rothsten oli myös itse kunnostautunut sanakirjatyössä ensimmäisen SKS:n julkaiseman vieraskielisen sanakirjan, Latinais-suomalaisen sanakirjan (1864), laatijana. Varsinaisen Rothstenin ajan vieraskielisten sanakirjojen sarjan päätti E. S. Yrjö-Koskisen Suomalais-saksalainen sanakirja (1900), jonka esipuhetta edeltävät Rothstenille osoitetut muistosanat. Käytännössä Rothstenin vaikutus ulottui vielä 1900-luvun varhaisvuosien sanakirjoihin asti. SKS:n kustantamien sanakirjojen kultakaudesta voidaan monessa mielessä puhua Rothstenin kautena.

\section{Kustantajan vieraskielisiin sanakirjoihin kohdistamat odotukset}

Edellä on käsitelty yleisesti SKS:n harjoittamaa vieraskielisten sanakirjojen julkaisutoimintaa ja siihen liittyviä käytäntöjä. Tässä luvussa keskitytään SKS:n vieraskielisiin sanakirjoihin suoraan kohdistamiin odotuksiin: millaista hyötyä kustantaja odotti kunkin sanakirjahankkeen tuottavan sekä kansallisella että yksilön tasolla? Käsittely noudattaa pääosin kronologista järjestystä.

Varhaisin tarkasteltava teos, Rothstenin Latinais-suomalainen sanakirja (1864), jää pöytäkirjoissa varsin vähäisille maininnoille. Tutkijakunta antaa kyllä positiivisen ja laadukasta lopputulosta ennakoivan lausunnon teoksen ollessa ilmeisesti painatusta vaille valmis vuonna 1861 (1.1.1863 Suomi 1, 292-293). Seuraava hanke, Godenhjelmin Saksalais-suomalainen sanakirja (1873), oli pitkään tekeillä: vuosien 1866-1873 pöytäkirjoihin karttui merkintöjä maksetuista palkkioista, työn etenemisestä ja siitä, kuinka suurta luottamusta hanke seuran taholta nautti. Lopputuloksena oli "lavea teos, monenvuotisen ahkeruuden ja suuren taidon arvokas hedelmä, sisältönsä puolesta mitä tärkeimpiä kirjallisuutemme tuotteita" (1.1.1878 Suomi 12, 219). Vuonna 1878 Godenhjelm itse lausuu suomalais-saksalaisen sanakirjan julkaisemista varten nimetyn komitean puolesta suuntaviivoja teoksen toimitustyölle (1.1.1879 Suomi 13, 425-427): tärkeintä on käytännön tarpeisiin vastaaminen. Teoksen tuli olla suomalaisille avuksi saksan kirjoittamisessa ja saksankieliselle käyttäjäkunnalle suomenkielisen kirjallisuuden lukemisessa. Maisteri Karl Ervastin - joka loppujen lopuksi tuli kirjan toimittajaksi - ehdotusta ottaa teokseen kantasanoja mahdollisimman kattavasti komitea toppuuttelee: teoksen tuli seurata ennen kaikkea kirjakielen sanastoa. Sanakirjan laatijan tulee pitää silmällä kirjallisuutta, johon saksalainen lukija tyypillisesti tarttuu: etupäässä Kalevalaa ja Kanteletarta mutta myös Kiven teoksia. Komitea suosittaa varovaisesti hakusanojen valinnan esikuvaksi F. Ahlmanin Suomalais-ruotsalaista sanakirjaa (1874). Samalla sanakirja "olisi kumminkin verrattava Lönnrot'in sanakirjaan ja tekijän tulisi itse päättää, mitkä sanat ovat otettavat" (1.1.1879 Suomi 13, 426). Komitean vaatimus on ristiriitainen, koska Ahlmanin ja Lönnrotin sanakirjat ovat varsin erilaisia. 
Kulttuurisia siltoja koetettiin rakentaa SKS:ssa vielä laajemmin kuin mitä lopulta reaalistui sanakirjoiksi. Epäonnistuneet sanakirjahankkeet kertovat kuitenkin mielenkiintoisella tavalla siitä, millaisia toimintatapoja ja tavoitteita seuralla oli. Merkittävimmät kariutuneista hankkeista olivat molemmat sihteeri Rothstenin suunnitelmia, minkä johdosta niistä on raportoitu pöytäkirjoissa poikkeuksellisen tarkasti. Vuonna 1864 käynnistettiin (muinais)kreikkalais-suomalaisen sanakirjan laatimista koskeva projekti (1.1.1868 Suomi 7, 377). Sanakirja osoittautui kuitenkin seuralle mahdottomaksi kustannettavaksi - Rothstenin laskelmien mukaan työ olisi vienyt vähintään kaksitoista vuotta (1.1.1868 Suomi 7, 358). Suunnitelma haudattiin muutaman vuoden kuluttua.

Kreikkalais-suomalaisen sanakirjan laadintaan ei tiettävästi sittemmin enää ryhdytty, vaikka teoksen puutetta valiteltiin vielä pitkään Rothstenin hankkeen kaaduttua. Lehtori Kaarlo Forsman jätti vuonna 1884 SKS:lle ehdotuksen laajan Homeros-sanakirjan laatimiseksi (1.1.1885 Suomi 18, 263). Asetettu komitea puolsi hanketta vedoten paitsi oppikouluissa vallitsevaan huutavaan kreikkalais-suomalaisen sanakirjan pulaan myös Homeroksen ainutlaatuiseen asemaan (sekä kirjallisuutena että kielellisesti) ja vielä nuorisossa Homeroksen myötä heräävään kiinnostukseen vertailevaa kielitiedettä kohtaan (1.1.1885 Suomi 18, 289-292). Lausunto on kiinnostava: suomenkielisen oppikoululaitoksen $\operatorname{tarpeet}^{6}$ ovat perusteluina odotuksenmukaisia, mutta uusien sukupolvien kasvattaminen kielitieteelliseen ajatteluun ennakoi jo suomalaista tieteenharjoittamista. Komitean puoltoretoriikka - joka ei sinänsä ole totuudenvastaista vaikka ehkä osin optimistista - vaikuttaa osuvalta, olihan SKS:ssa herätty keskustelemaan julkaisutoiminnan viemisestä tieteellisempään suuntaan, kuten edellä on nähty. Positiivisesta lausunnosta huolimatta tämäkään hanke ei toteutunut.

SKS:n 1800-luvun sanakirjahankkeista raskaimmin lienee epäonnistunut Rothstenin Latinais-suomalaisen sanakirjan laajennus, jonka tavoitteista ja periaatteista käytiin perusteellisia keskusteluja. Rothsten osoittaa kuunnelleensa käyttäjäkunnan mielipiteitä teoksesta ja esittää parannuksia pitkälti niihin perustuen (1.1.1879 Suomi 13, 263-266). Revisiotyöllä oli kiire, sillä painos oli loppumassa. Asiaa käsittelemään nimetty komitea kiinnitti huomiota paitsi latinan- myös suomenkielisen sanaston parannuksiin. Kirjakielen vakiintumisen kannalta suomalaisaineistoa, kuten murreilmauksia ja sepitettyjä, vakiintumattomiksi jääneitä sanoja (esim. mukaelmas, tekemö, sotio), tulikin tarkastella kriittisesti, sillä ne laajensivat teosta tarpeettomasti ja aiheuttivat hämmennystä. Asiantuntijat kuitenkin myös kiittivät vivahteikkaan kääntämisen mahdollistavaa sanavastineiden runsautta. (1.1.1879 Suomi 13, 326.) Omakielisen sanakirjan puute hankaloitti osaltaan myös yliopisto-opetusta ja jätti suomenkieliset opiskelijat ruotsinkielisiä huonompaan asemaan. Komitean muista ehdotuksista mielenkiintoisin oli, että teokseen lisättäisiin latinankielisiä sanoja vastaavat kreikkalaiset sanat, mikä merkitsi työmäärän kasvattamista edelleen ja painatuksen hankaloitumista kustannusten noustessa (1.1.1879 Suomi 13, 337). Seura taipui ehdotuksiin. Uutta laitosta odoteltaessa jouduttiin kuitenkin

6 1800-luvun oppikoulujen opetuksesta ks. Hanho 1955; Kiuasmaa 1982. 
suuressa sanakirjan puutteessa ottamaan uusintapainos vanhasta teoksesta 1.1 .1885 Suomi 18, 229). Tämä jäi Rothstenin sanakirjan viimeiseksi versioksi.

Erinomainen esimerkki onnistuneen sanakirjaprosessin etenemisestä on Suomalaislatinaisen sanakirjan laatimishanke. Rothsten esitteli tällaisen sanakirjan puutetta vakuuttavasti seuran kokouksessa vuonna 1875 (1.1.1878 Suomi 12, 269-272). Tässä yhteydessä pöytäkirjoissa puhutaan yksinomaan koulujen tarpeista (1.1.1878 Suomi 12, 289). Teoksen laatijaksi valikoitui lehtori J. G. Geitlin, joka vaikuttaa nauttineen järkkymätöntä arvostusta koko prosessin ajan. Vihdoin vuonna 1883 seura ilmoittaa tyytyväisenä kirjan olevan kirjakaupoissa ja saaneensa käyttöönsä "paraimmat pedagogilliset ja tieteelliset voimat, mitä sillä alalla maassamme löytyy". Teostakin kiitettiin oivalliseksi ja tarkoituksenmukaiseksi. Erityisesti korostettiin sen pedagogis-kulttuurisia vaikutuksia: latinan kielen opiskelun tarpeellisuutta loogisen ajattelun kehittäjänä ja eurooppalaiseen kulttuuriperintöön liittäjänä. Keskustelussa mainitaan myös teoksen olevan tervetullut apuneuvo ulkomaalaisille, jotka haluavat oppia suomea. (1.1.1883 Suomi 16, 535.) Tällä viitattaneen ennen kaikkea akateemisiin kontakteihin (ks. tark. Nummila-Seppänen 2018).

Ranskalais-suomalaista sanakirjaa koskevan hankkeen alkuvaiheissa keskusteltiin myös englantilais-suomalaisesta sanakirjasta. Todettiin, että jälkimmäinen olisi itse asiassa tarpeellisempi: teosta tarvitsisivat ainakin merimiehet. (1.1.1870 Suomi 8, 455-466.) Tällaisiin erikoistarpeisiin, tai ylipäätään muihin kuin akateemisiin käyttäjiin (joihin lukeutuvat myös oppikoululaiset), ei SKS:n yleissanakirjahankkeissa useinkaan viitata. Ranskalais-suomalaisen sanakirjan suhteen komitea antoi lausuntonsa ilmoittaen muun muassa sopiviksi katsomansa lähteet ja halutun laajuuden. Laatijaksi valittiin näytteiden perusteella kunnallisneuvos A. Meurman (1.1.1878 Suomi 12, 197, 206-207), joka toimitti myöhemmin myös Venäläis-suomalaisen sanakirjan (1895). Meurmanin sanakirjahankkeet etenivät moniin muihin verrattuna nopeasti: ensimmäiseen kului neljä vuotta eikä toiseenkaan juuri kauempaa. Seura näyttää suhtautuneen etenkin myöhempään hankkeeseen jo rutiinilla, eikä erityistä suitsutusta pöytäkirjoissa enää ilmene. E. S. YrjöKoskisen Suomalais-ranskalaisen sanakirjan (1900) osalta SKS piti ennakkoon tärkeänä, että se oli sekä suomalaisen että ranskalaisen käyttäjäkunnan tarkoituksiin sopiva. Teoksesta oli tarkoitus tehdä suhteellisen suppea paitsi taloudellisista syistä myös siksi, että tällaiselle teokselle nähtiin olevan käytännön tarve (1.1.1885 Suomi 17, 261-262). Rutiini sanakirjatyössä oli vahvistunut entisestään: edes varsinaisia perusteluja teoksen tarpeellisuudelle ei ole enää tallentunut pöytäkirjoihin.

\section{Sanakirjojen laatijoiden näkemysten ja kokemusten kirjoittuminen esipuheisiin}

SKS:n 180o-luvulla kustantamiin vieraskielisiin sanakirjoihin sisältyy tyypillisesti teoksen alkuun sijoitettu kirjan laatijan kirjoittama puheenvuoro. Kuten edellä todettiin, yhtä lukuun ottamatta kaikissa tarkasteltavissa teoksissa on sanakirjan laatijan esipuhe. Teksteistä neljä on nimetty alkulauseiksi, yksi esipuheeksi ja yksi on jätetty otsikoimatta. Käytämme teksteistä yhteisnimitystä esipuhe. Tarkasteltavat tekstit ovat noin 1-4 sivun mittaisia. 
Esipuheiden kieli on suomi, mikä ei ole vallitseva käytäntö muiden kustantajien saman aikakauden sanakirjoissa. Tyypillisistä lajipiirteistä huolimatta esipuheet eroavat toisistaan monin tavoin, vaikka ovat saman kustantajan yleissanakirjojen yhteyteen kirjoitettuja. Kustantaja onkin antanut kirjoittajalle varsin vapaat kädet esipuheiden laatimiseksi ja äänensä kuuluviin saattamiseksi. Eroista huolimatta tekstien tärkeimpinä tavoitteina nousevat esiin 1) teokseen liittyvien keskeisten asioiden (käyttötarkoitus, sanaston alkuperä ja yleiset toimitusperiaatteet) esitteleminen, 2) julkaisun valmistumiseen vaikuttaneiden tahojen kiittäminen ja 3) toimitustyöhön liittyvien epäkohtien selitteleminen.

Kirjoittajat esittelevät esipuheissa näkemyksiään toteuttamistaan toimitusperiaatteista. Teosten lähtökohdat ovat poikenneet toisistaan siinä, että osa teoksista on suomi kohdekielenä- (Rothsten 1864, Godenhjelm 1873, Meurman 1877, Meurman 1895) ja osa suomi lähtökielenä -sanakirjoja (Geitlin 1883, Ervast 1888, Yrjö-Koskinen 1900). Ensin mainituissa toimitustyön perusta on ollut huomattavasti jälkimmäisiä yksinkertaisempi, koska hakusanaston koostamisessa on voitu hyödyntää suoraan aiemmin ilmestynyttä johonkin toiseen kielipariin perustuvaa ja hyväksi havaittua teosta. Hakusanaston koostamisen haastavuudesta raportoivat kuitenkin myös suomi kohdekielenä -sanakirjojen laatijat, sillä käytännössä yksikään sanasto ei perustu kokonaisuudessaan mihinkään aiempaan teokseen. Erityisen ongelmallisen tilanteen eteen joutui Godenhjelm Saksalaissuomalaista sanakirjaa laatiessaan. Työn pohjana oli SKS:n vuonna 1863 lääketieteen tohtori Samuel Roosilta saama käsikirjoitus, jonka täydentämisen ja julkaisukuntoon toimittamisen Godenhjelm oli saanut tehtäväkseen. Hän kirjoittaa seuraavasti:

- - ryhdyin työhön, noudattaen Kirjallisuuden Seuran ohjeita ja tehden ainoasti wähäisempiä muutoksia korjattavassa käsikirjoituksessa. Waan jota edemmäksi pääsin ja jota tyystemmin koetin tarkastella saksalaisten sanojen eri merkityksiä ja käytäntöä sekä sowittaa selitykset suomenkielen waatimuksia myöden, sitä selwemmin huomasin, ett’ei tämmöinen työnteko woinut taata teoksen kelwollisuutta, samalla kuin se oli yhtä waiwaloinen kuin sanakirjan uudesti kirjoittaminen. - - käsikirjoitus oli, näet, melkein suora käännös Heinrich’in sanakirjasta, ${ }^{7}$ jonka ruotsalaiset merkitykset enimmitten oliwat taitawasti suomennetut. Waan jokainen, ken wähänkin on näitä seikkoja ajatellut, ymmärtänee, ett’ei sanakirjaa saa kääntämällä aikaan, ei ainakaan, jos asia koskee niin eriluontoisia kieliä, kuin nyt puheena olewat - - (Godenhjelm 1873, III).

Godenhjelmin sanoista voi päätellä, etteivät SKS:n antamat ohjeet päteneet aina käytännössä. Kirjoittaja ilmoittaakin joutuneensa muuttamaan taktiikkansa d-kirjaimen puolivälistä lähtien, mikä on aiheuttanut teokseen epätasaisuutta (mts., III). Kesken työn muuttuneista toimitusperiaatteista raportoi myös Geitlin Suomalais-Latinaisen sanakirjansa (1883) esipuheessa. Hän ilmoittaa periaatteiden vaihtumisen johtuvan kohderyhmän uudelleenmäärittelystä. Geitlin toteaa sisällyttäneensä teokseen alun perin oppilaiden

7 Carl Heinrich, Tyskt och svenskt handlexicon (1. p. 1818). 
kirjoitusharjoituksissa tarvitsemat sanat ja noudattaneensa tätä periaatetta hakusanoissa a-k. Noin kolmanneksen työstä ollessa valmiina hän joutui omien sanojensa mukaan useilta tahoilta tulleiden kehotusten seurauksena ottamaan rinnakkaiseksi tavoitteekseen suomen kielen esittelemisen ulkomaalaisille lukijoille. Geitlin ei kritisoi tavoitetta mutta ilmaisee selvästi periaatteiden muuttumisen vaikuttaneen teokseen kielteisesti. Hän ei mainitse suoraan, ketkä muutosta edellyttivät, mutta samoihin aikoihin tekeillä olleen Ervastin Suomalais-saksalaisen sanakirjan (1888) esipuhe on paljastava:

Toinen hankaluus on tullut siitä, että Suomalaisen Kirjallisuuden Seura määräsi teokselle kaksi tarkoitusta. Kirjan piti, näet, sekä täyttämän Suomen kouluissa tuntuva tarve että myöskin auttaman ulkomaalaisia tutustumaan Suomen kieleen ja kirjallisuuteen. Että tästä on syntynyt paljo epätasaisuuksia, ei liene muuta kuin luonnollista. Sillä milloin on mikin tarkoitus päässyt voiton puolelle. Tätä epäkohtaa on minun ollut mahdoton välttää, vaikka kuinkakin olen koettanut. (Ervast 1888.)

Vastaavan ohjeen on saanut SKS:n kolmannen suomi lähtökielenä -sanakirjan laatija E. S. Yrjö-Koskinen, joka toteaa Suomalais-ranskalaisen sanakirjan (1900) esipuheessa kaksinaisen tarkoitusperän laajentaneen kirjan kokoa ja vaikeuttaneen työn suoritusta. Myös hän toteaa, ettei aina ole ollut helppo ratkaista, kumpaa näkökohtaa tulisi pitää ensisijaisena. Jostakin syystä kirjoittajien mainitsema tavoite ei ole tallentunut pöytäkirjoihin. Esipuheista saakin käsityksen, että kirjoittajat ovat kyllä saaneet kustantajalta ohjeistusta teosten laatimiseksi, mutta neuvot eivät ole olleet loppuun asti ajateltuja tai ainakaan vielä vakiintuneita eikä niitä ole välttämättä annettu kirjoittajille evästyksinä työn alussa. Yrjö-Koskinen toteaa esipuheessaan saaneensa SKS:n tutkijakunnalta aivan työnsä loppuvaiheessa teoksen sisältövaatimukset vastauksena lähettämiinsä sanakirjan näytearkkeihin. Tämän ohjeen mukaan sanakirjan tulisi sisältää 1) kaikki suomen kirjakielessä ja sivistyneessä puheessa yleisesti käytetyt sanat ja lauseparret, 2) kansallisrunoelma Kalevalan sanaston ja 3) eri alojen tavallisimmat tiede- ja ammattisanat sekä tavallisten kasvien ja eläinten nimet. Yrjö-Koskinen kommentoi ohjeistusta välistä melko kitkerään sävyyn:

Jokainen asiaa lähemmin ajatellut ymmärtää, kuinka epämääräinen, tekiän omasta käsityksestä ja aistista kokonaan riippuvainen on se määräys, että sanakirjan tulee sisältää kirjakielessä ja sivistyneessä puheessa yleisesti käytetyt sanat ja lauseparret. Mutta valinnan vaikeus on sitä suurempi, kun se koskee kieltä joka varsinkin sanasynnyn ja -muodostuksen puolesta on sellaisessa kuohuvassa luomistilassa kuin suomenkieli. (Yrjö-Koskinen 1900, VII.)

Kohderyhmän valinnan ja yleisten toimitusperiaatteiden lisäksi esipuheissa nousevat voimakkaasti esiin kieliasuun liittyvät teemat, niin oikeinkirjoituskysymykset kuin tahattomat virheet. Kaikki kirjoittajat ottavat kantaa näihin seikkoihin ja lähes kaikki osoittavat olevansa teoksensa kieliasusta huolissaan ja pahoittelevat sanakirjaansa päätyneitä virheitä. Ervast kirjoittaa: 
- - työhön ryhtyessäni, olin peräti tottumaton korrehtuurin lukija. Vaivaani en laske miksikään; mutta kun lopulta huomaa, että kirjassa semmoisessa, jossa ei saisi yhtäkään painovirhettä olla olemassa, niitä kuitenkin tavataan, niin mieltä masentaa, kun tietää parasta tavoittaneensa. (Ervast 1888.)

Kirjoittajat harmittelevat myös kieliasun epätasaisuutta ja sitä, että alkuosassa noudatettujen käytäntöjen vakiintumattomuus on aiheuttanut suuria eroja loppuosaan nähden. Sanakirjan laatijalta lähteneen käsikirjoituksen tuli olla painokuntoinen. Käytännössä kirjoittaja joutui myös jättämään aiempia osia painettavaksi ennen myöhempien valmistumista. ${ }^{8}$ Godenhjelm toteaa:

- - teoksen alusta sen, niin sanoaksemme, sana-kirjallinen ulkomuoto on wielä aivan vakaantumaton ja monessa kohden poikkee siitä, mitä edempänä kirjassa on tawaksi otettu. Paitsi sitä ruwettiin teosta painamaan melkein kohta sen jälkeen, kuin olin työhön ryhtynyt, ja painamista joudutettiin työn ensi-aikoina ylen suurella kiiruulla, johon ainoasti silloinen kokemattomuuteni ja tietämättömyyteni tällaisen työn laadusta sai minun suostumaan - -. (Godenhjelm 1873, IV.)

Esipuheiden keskeistä sisältöä ovat prosessiin tavalla tai toisella osallistuneille kollegoille ja muille toimijoille osoitetut kiitokset. Tyypillisiä kiitettäviä ovat kieliasua korjanneet henkilöt. Kiinnostava kysymys on, minkälaista konkreettista kieliasuun liittyvää ohjeistusta sanakirjan kirjoittaja sai seuralta. Godenhjelm (1873) toteaa seuranneensa parhaansa mukaan suomalaissanaston oikeinkirjoituksen osalta sääntöjä, "jotka oli määrätty Suomalaisen Kirjallisuuden Seuran toimesta vuotta ennen alotettua ruotsalais-suomalaista sanakirjaa varten”. Tässä viitataan Ahlmanin vuonna 1865 julkaistuun teokseen. Myöhemmät kirjoittajat eivät ohjeistusta mainitse. Myös Godenhjelm jatkaa heti edellä esitetyn perään, että monet säännöt poikkeavat sittemmin käyttöön vakiintuneista tavoista ja ohjeista. Huomattakoon, että Godenhjelm toimi itse sanakirjaa valmistellessaan SKS:n tutkijakunnan jäsenenä (Krohn 1931, 28). Ervast (1888) puolestaan nimeää kielelliseksi esikuvakseen Lönnrotin sanakirjan ja toteaa luottaneensa siihen aina ehdottomasti "tohtimatta poiketa, vaikka usein olisikin haluttanut". Ervast lisää, että muutamissa kohdin hän on kuitenkin rohjennut käyttää toista tapaa. Esipuheet heijastelevat aikakaudella oikeinkirjoituksen vakiinnuttamispyrkimyksistä käytyä vilkasta keskustelua.

Esipuheiden yhtenä tehtävänä on esitellä toimitustyötä rasittaneita tekijöitä ja selittää työssä ilmeneviä epäkohtia. Jo mainittujen seikkojen lisäksi kirjoittajat vetoavat kokemattomuuteensa ja puutteellisiin taitoihinsa. SKS pyrki valitsemaan työhön parhaat mahdolliset tekijät; osa kirjoittajista kuitenkin pahoittelee muun muassa kielitaitonsa rajallisuutta. Geitlin (1883) kirjoittaa: ”Tiesinpä jo edeltäpäin arwata niitä monenlaisia

8 Teoksen alkuosan painamiseen ryhtyminen ennen kokonaisuuden valmistumista oli SKS:n vakiintunut käytäntö, joka joudutti huomattavasti sanakirjan markkinoille päätymistä (1.1.1883 Suomi 16, 509). 
waikeuksia, jotka tämmöinen yritys tuottaisi etenkin sille, joka, kuten minä, wasta miehen ikään päästyäni oli alkanut Suomen suloista kieltä opiskella”. Yrjö-Koskinen (1900, VII) toteaa: "Tekiä ei ole työnsä varrella hetkeäkään luuletellut osaavansa ranskaa siinä määrin kuin tämänlaisen teoksen täysin arvokkaaseen suoritukseen vaadittaisiin". Esipuheissa selitetään puutteita ja työn viipymistä vetoamalla olosuhteisiin, virkatyöstä ja muista tehtävistä johtuvaan ajanpuutteeseen ja tehtävän yleiseen suuritöisyyteen. SKS:n 1800-luvun vieraskieliset sanakirjat edustivat myös tyypillisesti pioneeritöitä. Rothsten päättää esipuheensa seuraavasti:

Työ oli waikia. Harwa aimollinenkaan kylmään maahan kelwollisen waon kyntää, saatikka wähäkuntoinen. Waan järkimiehet tietäwät, mitä ensi kokeelta kohtuudella woi waatia. Heidän päätöksiinsä minä turwaan. Warmaan he eiwät wastaalkajan hywänaikeista yritelmää liian ankarasti tuomitse. (Rothsten 1864, VI.)

Esipuheiden keskeisenä tavoitteena on informoinnin lisäksi vaikuttaa lukijaan, mikä on nähtävissä myös edellä siteeratussa Rothstenin puheenvuorossa. Vuorovaikutuksen ja tekstienvälisen dialogin näkökulmasta 1800 -luvun esipuheiden tehtävänä on vastaanoton ennakoiminen. Vastaanottajana voidaan nähdä kirjaa käyttävä koululainen mutta myös teosta arvioiva asiantuntijayleisö, näiden mukana kirjasta julkisen arvion laativa arvioitsija. Esipuheiden selittelevyys, puolustelevuus ja nöyristelevyys kuvastavat ajan käytänteitä. Hyväksytyksi tuleminen vaatii yhteisön odotuksia vastaavaa retoriikkaa (ks. myös Szalai 2006). Esipuheet osoittavat myös, että puolustautumisen nimissä tekstissä on voinut esittää kustantajaankin kohdistuvaa kritiikkiä. 180o-luvun pienissä piireissä ei varmasti ollut kenenkään etu ajautua huonoihin väleihin SKS:n kaltaisen toimijan kanssa. Esipuheiden kielenkäyttö kuvastaakin aikakauden tapoja mutta viestinee myös henkilöstön ja sanakirjan laatijoiden suhteiden tietynlaisesta avoimuudesta.

\section{Sanakirjat kriitikoiden silmin}

Kaikki tutkimuksessa käsiteltävät sanakirjat arvioitiin aikanaan aikakausjulkaisuissa. Kuten edellä todettiin, teosten arvioijina toimivat tyypillisesti alansa arvostetut asiantuntijat. Rothstenin Latinais-suomalaisen sanakirjan arvioi Rooman kirjallisuuden dosentti Johan Albert Söderholm (1864, Litterär tidskrift utgifven i Helsingfors) ja Godenhjelmin Saksalais-suomalaisen sanakirjan sanskritin ja vertailevan kielentutkimuksen professori Otto Donner (1874, Kirjallinen Kuukauslehti). Godenhjelmin teoksen arvioi myös suomen kielen professori August Ahlqvist (1874, Kieletär). Godenhjelm, joka toimi yliopiston saksan kielen lehtorina, laati arviot sekä Meurmanin Ranskalais-suomalaisesta että Ervastin Suomalais-saksalaisesta sanakirjasta (1874, Kirjallinen Kuukauslehti ja 1891, Valvoja). Geitlinin Suomalais-latinaisen sanakirjan arvioi latinan kielen lehtori Adolf W. Streng (1884, Valvoja), Meurmanin Venäläis-suomalaisen sanakirjan slaavilaisen filologian dosentti J. J. Mikkola (1895, Valvoja) ja Yrjö-Koskisen Suomalais-ranskalaisen sanakirjan 
ranskan kielen lehtori Axel Rosendahl (1901, Tidskrift utgiven av pedagogiska föreningen $i$ Finland). ${ }^{9}$ On syytä huomata, ettei mainittuja julkaisukanavia voi pitää kaikin osin neutraaleina. Esimerkiksi Kirjallinen Kuukauslehti tunnettiin SKS:n ja sen pitkäaikaisen esimiehen Yrjö-Koskisen kannattajien äänitorvena; Ahlqvistin toimittama Kieletär oli puolestaan hänen henkilökohtainen fooruminsa (esim. Häkkinen 1994, 507; PaloposkiRiikonen 2013, 602). Toisaalta, kuten tullaan näkemään, SKS:lle myötämielisissäkään lehdissä ilmestyneet arviot eivät ole millään muotoa pelkästään suopeita.

Sanakirja-arvioiden laajuudet vaihtelevat vajaasta kahdesta sivusta neljääntoista sivuun. Tavallista on, että arvioijat kiinnittävät huomiota sekä toimitusperiaatteisiin, joista he löytävät poikkeuksetta kritisoitavaa, että teokseen eri syistä jääneisiin virheisiin ja puutteisiin. Pääsääntöisesti arvioijat kuitenkin suhtautuvat melko suopeasti yksityiskohtaisestikin selvittelemiinsä epäkohtiin ymmärtäen paitsi pioneerityön haasteet myös jatkuvan painatustavan, joka ei sallinut taannehtivaa korjaamista, vaikka teos ei kokonaisuudessaan olisikaan ollut vielä valmis.

Yleisesti voidaan todeta, että 1800-luvun sanastoteosten arvioista löytyy varsin suorasukaisiakin lausuntoja, mutta SKS:n kustantamia sanakirjoja koskeva (julkinen) keskustelu säilyy maltillisena. Henkilökysymysten osalta on tunnettua, että 1800-luvun sivistyneistön piirit olivat suppeat ja eri alojenkin toimijat tunsivat toisensa. Yhtä lailla tiedetään, etteivät kaikkien kielimiesten ja SKS:n piirissä toimineidenkaan henkilökemiat sopineet yhteen (esim. Sulkunen 2004). Seuran pöytäkirjoissa mahdolliset ristiriidat sanakirjahankkeiden yhteydessä eivät kuitenkaan juuri näy, eikä niitä ilmaista ainakaan eksplisiittisesti myöskään arvioissa. Joidenkin SKS:n sanakirjoja arvioineiden asiantuntijoiden suhde seuraan oli kiinteä: Godenhjelm, Donner ja Streng toimivat aikanaan näkyvissä rooleissa SKS:ssa. Toisaalta Söderholm, Rosendahl ja Mikkola eivät olleet edes seuran jäseniä. Arvioijista ristiriitaisin suhde SKS:aan oli Ahlqvistilla, joka entisenä aktiivitoimijana riitautui seuran ja erityisesti sen pitkäaikaisen esimiehen Yrjö-Koskisen kanssa. Tulehtuneiden välien on katsottu vaikuttaneen Ahlqvistin SKS:n kustantamia teoksia käsitteleviin arvioihin (ks. Häggman 2008, 200). Tarkasteltavista sanakirjoista hän arvioi kuitenkin vain Godenhjelmin teoksen. Arvio on kriittinen mutta asiallinen - varsinkin kun otetaan huomioon, että Ahlqvist on tunnettu arvioidensa karkeudesta ja jopa kohtuuttomuudesta (ks. tark. Kohtamäki 1956, 415-427).

Arvioijien tarkoitus on ennen kaikkea olla hyödyksi lukijalle. Tämä näkyy heidän pyrkimyksenään perustaa kritiikkinsä teoksen käytettävyyteen. Näin toimivat esimerkiksi Godenhjelm (1878, 257-258) ja Mikkola (1895, 184) arvioidessaan Meurmanin sanakirjoja: testin vuoksi he ovat koettaneet lukea sanakirja apunaan satunnaisia tekstiotteita joiltakin merkittäviltä ranskan- ja venäjänkielisiltä kirjailijoilta. Godenhjelmin

9 Arvioijat esiintyvät ajan tapaan pääsääntöisesti nimikirjaimillaan, joista ei ole kuitenkaan vaikea päätellä, kenestä on kyse, paitsi Rothstenin sanakirjan arvioijan "Shm." osalta. Todennäköisesti kyseessä on Rooman kirjallisuuden dosentti J. A. Söderholm, joka toimi Helsingfors Lyceumin kreikan kielen opettajana (Kotivuori 2005). Samainen "Shm." oli myös pätevä arvioimaan Litterär tidskriftissä (1865, nro 1) Gustaf Cannelinin Kreikan kieli-opin. 
Saksalais-suomalaista sanakirjaa arvioidessaan Donner $(1874,183)$ toteaa, että tällainen arvio olisi paikallaan, mutta hänellä ei ole ollut tilaisuutta perehtyä kirjaan käytön kannalta. Strengin arvio Geitlinin Suomalais-latinaisesta sanakirjasta suorastaan viivästyi huomattavasti siksi, että hän nimenomaan halusi ennen mielipiteensä lausumista käyttää teosta työssään latinan kielen lehtorina havaitakseen sen puutteet ja ansiot.

Siinä missä suomi kohdekielenä -sanakirjoja on järkevää arvioida edellä kuvatulla tavalla - lukemalla vieraskielisiä tekstejä sanakirjan avulla - suomi lähtökielenä -sanakirjoissa huomio kiinnittyy toisenlaisiin asioihin. Ilmeinen ongelma on sanastopohja, mikä todettiin myös esipuheiden käsittelyn yhteydessä. Ervastin sanakirjaa arvioidessaan Godenhjelm $(1891,38)$ myöntää vaikeudeksi sen, ettei työn pohjaksi täysin soveltuvaa suomalaista sanalistaa ole olemassa. Ervastin käyttämä Ahlmanin Suomalais-ruotsalainen sanakirja (1874) ei uusien sanojen suhteen riitä, vaikka onkin Lönnrotia parempi. Soveltuvan pohjasanaston puute vaivaa myös Geitlinin Suomalais-latinaista sanakirjaa (1883). Strengilläkään $(1884,462)$ ei ole arviossaan esittää muuta jälkikäteissuositusta sanastopohjaksi kuin Ahlman; Lönnrotin seuraamista hän pitää valitettavana ratkaisuna sanakirjan oppikirjana käyttämisen kannalta. Geitlinin teoksen suurimmaksi ongelmaksi nousee Strengin (1884, 458-459) mukaan se, mitä sanakirjan laatija itsekin piti ongelmallisena: teokseen on pitänyt sisällyttää runsaasti sanastoa, jota ulkomaalainen käyttäjä mahdollisesti tarvitsisi (etupäässä Kalevalan lukemiseen) mutta jota suomalainen ei tietäisi kaivata, koska kyse ei ole jokapäiväisestä sanastosta. Kalevalaissanastokin on teoksessa kuitenkin epätäydellinen. Jälkiviisaasti voi myös todeta, että ulkomaisen lukijakunnan palveleminen - mikä oli SKS:n tavoitteena - jäi varmasti vähäiseksi, kun lopulta Geitlinin (suomi-muinaiskieli-)sanakirjan ja Ervastin (suomi-nykykieli-)sanakirjan valmistumisten väliin jäi edellisen viivästymisen vuoksi vain viisi vuotta.

Negatiivisimman arvion teoksista saa Yrjö-Koskisen Suomalais-ranskalainen sanakirja Rosendahlilta (1901). Vaatimukset alkavat olla korkealla, sanakirja on ollut työn alla huomattavan pitkään ja lopputulos on heikonlainen. Rosendahl kiinnittää erityistä huomiota työssä käytettyihin lähteisiin, jotka eivät ole ajantasaisia ja luotettavimmiksi todettuja. Ongelmallisena hän pitää myös käytäntöä, jossa ranskan osalta ei erotella eri rekisterien tai aikakausien sanoja tai harvinaisia ja tavallisia sanoja; tämä hankaloittaa käyttöä huomattavasti. Rosendahlin arvio teoksesta kaikkiaan on, että se on toimitettu epätieteellisesti. Yrjö-Koskinen itsekin sivuaa asiaa esipuheessaan: kustantaja SKS on pyytänyt häntä välttämään "kaikkia puhtaasti tieteellistä käsittelyä, joka ei käytännöllisesti mitään merkitse". Käytännössä lopputulos oli kuitenkin ongelmallinen myös suomalaiseen kirjallisuuteen tutustuvalle ranskankieliselle, sillä sanasto ei riittänyt uuden kirjallisuuden parhaimmistonkaan (josta Rosendahlin esimerkkinä on Juhani Aho) lukemiseen. Rosendahlkin kuitenkin päättää arvionsa lausumalla, että teos "vastaa kohtuullisia vaatimuksia". (Rosendahl 1901, 219-222.) SKS:n ohjeistus - joka ei Yrjö-Koskisen esipuheessaan välittämässä muodossa ole tallentunut pöytäkirjoihin - on jälleen osoittautunut käytännössä hankalaksi toteuttaa.

Sanaston ajantasaisuus puhuttaa myös Ahlqvistia tämän Godenhjelmin Saksalais-suomalaista sanakirjaa (1873) käsittelevässä arviossa. Teos saa toisaalta kritiikkiä keskeisen 
nykysanaston puutteesta ja toisaalta vanhentuneen sanaston viljelystä. Ahlqvist kritisoi myös kirjakieleen kuulumattoman murresanaston mukana oloa ja liikojen synonyymien luettelua. Hän näkee, että taitava sanakirjan tekijä voisi omilla valinnoillaan edistää kirjakielen vakiintumista. (Ahlqvist 1874, 56-59.) Kiinnostavaa on, että Ahlqvistin kritiikki koskee täsmälleen niitä asioita, joita SKS:n tutkijakunta oli joitakin vuosia aiemmin kannanotossaan (1865) suosittanut (ks. edellä luku 3). Ahlqvist oli tällöin itse tutkijakunnan jäsen (esim. Krohn 1931, 27).

Kirja-arvioihin nykyäänkin tyypillisesti kuuluvien sisältöhuomioiden lisäksi ${ }^{1800-}$ luvun sanakirjojen arvioijien esillä pitämä teema on kansallinen kiitollisuus. Ehkäpä voimakkaimmin asian ilmaisee Donner (1874, 184): "Suomalainen kirjallisuus on aina oleva kiitollinen lehtori Godenhjelmille hänen huolellisesta ja lemmekkäästä työstänsä tämän sanakirjan laatimisessa.” Miltei jokaisessa arviossa nousee esiin myös sanakirjan tienraivaaja-aseman kunnioittaminen ja sen myötä teoksen merkittävyys - teema, jonka sanakirjan kirjoittajat nostavat myös itse mielellään esiin esipuheissaan. Söderholm (1864, 507) tähdentää arviossaan Rothstenin Latinais-suomalaista sanakirjaa edeltävän suomalaisen sanakirjatradition ohuutta ja peilaa Rothstenin ansioita siihen: työ on taidolla tehty, sen kypsyyttä ja tarkkuutta sopii kiittää eikä tekijä ole säästellyt vaivojaan. Sanankäänteet tekevät selväksi, kuinka arvokkaana hän syntynyttä latinan sanakirjaa pitää.

Toisaalta Söderholmin (1864) arvion varsinainen analyyttinen osuuskin on kattava. Palstatilaa käytetään muun muassa sen pohtimiseen, kumpi on järkevämpi tapa järjestää hakusanat, täysin aakkosellinen (kuten Rothstenilla) vai niin sanottu derivatiivinen metodi, jossa aakkostaminen perustuu kantasanoihin, joiden yhteydessä esitellään yhdyssanat ja johdokset. Kysymys on tärkeä päätettäessä käytännöllisyyden ja tieteellisyyden välillä. Jälkimmäinen ei tule "koulujen tarpeeksi" laaditussa sanakirjassa kyseeseen ja olisi myös laatijalle edellistä vaativampi toteutettava. Söderholm kuitenkin korostaa tällaisen derivatiivisen tarkastelun merkitystä kielitaidon kasvattamisessa. Toisaalta Rothstenin sanakirja on arvioijasta koulujen tarpeisiin liian laaja (lähinnä selitysosioltaan) ja kallis samalla se on kuitenkin varsinaiseksi latinan sanakirjaksi auttamatta rajoittunut, koska se ei ota huomioon kuin niin kutsutun kultakauden latinan. Söderholm ei kuitenkaan nosta arviossaan esiin varsinaisia käyttäjäkokemuksia koulumaailmasta, jonka suomenkielisestä opetuksesta hänellä ei kaiketi ollutkaan henkilökohtaista kokemusta. Myös ulkomainen käyttäjäkunta nousee esiin: tuore sanakirja tulee herättämään kielitieteellistä kiinnostusta suomea, sen rakenteita ja sanastoa kohtaan. (Söderholm 1864, 510, 514-515.)

Kansallisen sivistyksen rakentaminen on yksi arvioiden keskeisistä teemoista. Godenhjelm $(1878,257)$ tervehtii Meurmanin ranskalais-suomalaista sanakirjaa "porttina", jonka kautta "virtaa sisään sivistyksen elähyttävä henki". Useassa arviossa korostetaan omakielisten apuneuvojen merkitystä; sanakirjoja, etenkin ruotsinkielisiä, on ollut saatavana, ja monet ovat niitä käyttäneetkin, mutta kuten Rosendahl $(1901,218)$ toteaa, "hankalata näet on yhden vieraan kielen välityksellä tunkeutua toisen vielä vieraamman kielen henkeen ja omistaa itselleen sen ilmaisu- ja katsomustapa”.

On nähtävissä, että SKS:n etukäteishehkutus vaikutti arvioiden sävyyn. Varhaiset Rothstenin (1864), Godenhjelmin (1873) ja Meurmanin (1877) sanakirjat saavat 
osakseen arvioissakin suurimmat ylisanat, kun taas myöhäisimmät Meurmanin (1895) ja Yrjö-Koskisen (1900) teokset saavat huomattavasti laimeamman vastaanoton. Todellisia ansioita tärkeämmäksi arvioissa nostetaan toistuvasti se, että teos on ylipäätään valmistunut - monen teoksen kohdalla tämä näyttikin varmaan pitkään jopa epätodennäköiseltä, ja kuten on nähty, merkittäviä hankkeita myös kaatui.

\section{Lopuksi}

Olemme tarkastelleet tutkimuksessamme SKS:n 1800-luvun vieraskielisten sanakirjojen kustannustoimintaa, siihen liittyviä tavoitteita ja sanakirjoihin kohdistuneita toiveita kustantajan, sanakirjojen laatijoiden ja teosten vastaanottajien näkökulmista. Prosessiin osallistuvien toimijoiden näkemyksiä on kartoitettu kolmenlajisista teksteistä koostuvasta tutkimusaineistosta. SKS:n toimintaa kuvaavat pöytäkirjat osoittavat, että seuran piirissä käydyissä keskusteluissa tärkeimmiksi syiksi laatia vieraskielisiä sanakirjoja nousivat koulujen tarpeet, luonnollisena jatkumonaan kulttuuristen näköalojen avautuminen ja näin suomalaisen kulttuurin rikastuttaminen merkittävien sivistyskielten kirjallisuuden kautta. SKS:ssa tavoiteltiin myös teosten korkeaa tasoa, mikä pyrittiin varmistamaan valitsemalla tekijät tarkkaan ja kontrolloimalla prosessia toimikuntien avulla.

Varhaisten vieraskielisten sanakirjojen pioneerityön luonne ja työhön liittyvät hankaluudet tulevat havainnollisesti esiin sanakirjojen esipuheista. Niissä kirjoittajat saavat oman äänensä kuuluviin ja tuovat varsin vapaasti esiin näkemyksensä erityisesti prosessiin liittyvistä epäkohdista. Esipuheiden puheenvuorot osoittavat, etteivät SKS:n sanakirjojen tekijöille antamat ohjeet olleet vielä loppuun asti mietittyjä tai toimitusperiaatteet selviä. Kesken prosessin muuttuvat ohjeet ja tavoitteet tuottivat jäljen epätasaisuutta ja hidastivat työtä. Monien tarpeiden samanaikaiset tyydyttämisyritykset epäonnistuivat käytännössä, ja tuloksina oli teoksia, jotka eivät palvelleet erityisen hyvin yhtäkään potentiaalista käyttäjäryhmää. Samat teemat ovat esillä myös sanakirjoista kirjoitetuissa arvioissa; niissä nousee kuitenkin voimakkaasti esiin myös pioneerityön arvostus ja kansallinen kiitollisuus. Puutteistaan huolimatta 1800 -luvun vieraskieliset sanakirjat olivat merkittäviä osoituksia kansallisen sivistyksen rakentamisesta ja suomen kielen ilmaisuvarannon rikkaudesta: suomi oli mahdollista esittää kielenkuvauksissa tasavertaisena muiden sivistyskielten rinnalla.

\section{Lähteet}

\section{Aineslähteet}

Ahlqvist, August 1874: Saksalais-Suomalainen Sanakirja. Deutsch-Finnisches Wörterbuch. Suomalaisen Kirjallisuuden Seuran Toimituksia, 49 osa. Kieletär, 6. vihko, 56-59.

Donner, Отто 1874: B. F. Godenhjelm, Saksalais-Suomalainen Sanakirja. Deutsch-Finnisches Wörterbuch. Helsingissä 1873. Kirjallinen Kuukauslehti 7, 182-184. 
Ervast, KARL 1888: Suomalais-saksalainen sanakirja. SKST 69. Suomalaisen Kirjallisuuden Seura, Helsinki.

Geitlin, Johan Gabriel 1883: Suomalais-latinainen sanakirja, Lexicon Fennico-Latinum. SKST 65. Suomalaisen Kirjallisuuden Seura, Helsinki.

GODENHJELM, BERNHARD FREDRIK 1873: Saksalais-suomalainen sanakirja. SKST 49. [2., uudistettu laitos 1906]. Suomalaisen Kirjallisuuden Seura, Helsinki.

1878: Kotimaan Kirjallisuutta. Dictionnaire Français-Finnois par A. Meurman - RanskalaisSuomalainen Sanakirja A. Meurman'ilta. Kirjallinen Kuukauslehti 11, 257-259.

_ 1891: Karl Ervast, Suomalais-Saksalainen Sanakirja. Finnisch-Deutsches Wörterbuch. Valvoja $11,38-42$.

Meurman, Agathon 1877: Ranskalais-suomalainen sanakirja. SKST 56. Suomalaisen Kirjallisuuden Seura, Helsinki.

1895: Venäläis-suomalainen sanakirja. SKST 84. Suomalaisen Kirjallisuuden Seura, Helsinki.

MikкolA, Jooseppi Julius 1895: A. Meurman, Venäläis-suomalainen sanakirja. Valvoja 15, 184-185.

Rosendahl, Axel 1901: Litteratur. E. S. Yrjö-Koskinen, Suomalais-Ranskalainen Sanakirja, Dictionnaire Finnois-Français. Suomalaisen Kirjallisuuden Seuran Toimituksia, 94 osa. Tidskrift utgiven av Pedagogiska föreningen $i$ Finland 4, 218-223.

RothSten, Frans Wilhelm 1864: Latinais-suomalainen sanakirja koulujen tarpeeksi. SKST 33. Suomalaisen Kirjallisuuden Seura, Helsinki.

Suomi. Suomalaisen Kirjallisuuden Seuran keskustelemukset 1860-1901.

SöDerholm, Johan Albert 1864: Latinais-Suomalainen Sanakirja koulujen tarpeeksi. (Latinsk-finsk ordbok för skolornas behof.) Litterär tidskrift utgifven i Helsingfors 8, 506-516.

Streng, Adolf Woldemar 1884: Kotimaan kirjallisuutta. Suomalaisen Kirjallisuuden Seuran Toimituksia 65 osa: Suomalais-Latinainen Sanakirja (Lexicon Fennico-Latinum) kirjoittanut Dr. Joh. Gabr. Geitlin. Valvoja 9, 457-471.

YrJÖ-Koskinen, EINo SAKARI 1900: Suomalais-ranskalainen sanakirja. SKST 94. Suomalaisen Kirjallisuuden Seura, Helsinki.

\section{Muut lähteet}

Ahlman, Ferdinand 1865: Ruotsalais-Suomalainen Sanakirja. Svenskt-Finskt Lexicon. SKST 38. Suomalaisen Kirjallisuuden Seura, Helsinki.

1874: Suomalais-Ruotsalainen Sanakirja. Finskt-Svenskt Lexicon. G. W. Edlund, Helsinki.

Haltsonen, Sulo 1931: Tilastotietoja julkaisutoiminnasta. Suomalaisen Kirjallisuuden Seura 18311931. Suomi 5:12. Suomalaisen Kirjallisuuden Seura, Helsinki.

Hanho, J. T. 1955: Suomen oppikoululaitoksen historia II, 1809-1872. WSOY, Porvoo.

HEINRICH, CARL 1818: Tysk och svenskt handlexicon. J. P. Lindh, Stockholm.

HäGgMAn, KaI 2008: Paras tawara maailmassa. Suomalainen kustannustoiminta 1800-luvulta 200o-luvulle. Otava, Helsinki.

2011: Sanojen talossa. Suomalaisen Kirjallisuuden Seura 189o-luvulta talvisotaan. SKST 1348. Suomalaisen Kirjallisuuden Seura, Helsinki.

HäKKINEN, KAISA 1994: Agricolasta nykykieleen. Suomen kirjakielen historia. WSOY, Helsinki.

2008: Suomen kielen historia 2. Suomen kielen tutkimuksen historia. Turun yliopiston suomalaisen ja yleisen kielitieteen laitoksen julkaisuja 78 . Turun yliopisto, Turku.

JANTUNEN, JARMO H. 2011: Käännöskritiikkiä 1800-luvun almanakoista. Sananjalka 53, 221-230.

KiUasmaA, Kyösti 1982: Oppikoulu 1880-1980: oppikoulu ja sen opettajat koulujärjestyksestä peruskouluun. Pohjoinen, Oulu.

KohtAmäкI, Ilmari 1956: August Ahlqvist suomen kielen arvostelijana. Helsinki.

KotivuORI, Yrjö 2005: Ylioppilasmatrikkeli 1640-1852: Johan Albert Söderholm. Saatavilla https://ylioppilasmatrikkeli.helsinki.fi/henkilo.php?id=16491>. Luettu 5.12.2017.

Koukkunen, Kalevi 2004: Kaikki sen tietävät - G. E. Eurénin Suomalais-Ruotsalaisen Sanakirjan 
(1860) synnyttämä polemiikki. Sananjalka 46, 106-124.

KoukKunen, KAlevi 2012: Kaikilla pitää piletit oleman walmisna - All must have their tickets ready. Suomalais-englantilaisten sanakirjojen historiaa. Sananjalka 54, 76-106.

2014: He sets his judgement by his passions - Hänen himonsa vaikuttavat hänen päätöksiinsä. Englantilais-suomalaisten sanakirjojen historiaa. Sananjalka 56, 139-170.

Kovala, URPO 2013: Kustannustoimen kehitys 1800-luvulla suomennetun tietokirjallisuuden näkökulmasta. Outi Paloposki ja H. K. Riıkonen (toim.): Suomennetun tietokirjallisuuden historia 1800-luvulta 2000-luvulle, 40-50. SKST 1289. Suomalaisen Kirjallisuuden Seura, Helsinki.

Krohn, KaArle 1931: Toimihenkilöt ja toiminnan puitteet. Suomalaisen Kirjallisuuden Seura 18311931. Suomi 5:12. Suomalaisen Kirjallisuuden Seura, Helsinki.

KäÄNTÄ, LIISA 2005: Oppikirjan esipuhe vuorovaikutuksena. Interpersoonaisten ja kontekstuaalisten merkitysten kriittinen analyysi. Pro gradu -tutkielma. Nykysuomen ja kääntämisen laitos. Vaasan yliopisto, Vaasa.

LÖNNROT, ELIAS 1866-1880: Suomalais-Ruotsalainen sanakirja. Suomalaisen Kirjallisuuden Seura, Helsinki.

NinivaAra, Martti 1931: Kielen tutkimus ja viljely. Suomalaisen Kirjallisuuden Seura 1831-1931. Suomi 5:12. Suomalaisen Kirjallisuuden Seura, Helsinki.

Nummila, Kirsi-Maria - Seppänen, Minna 2018: J. G. Geitlinin Suomalais-latinainen sanakirja (1883) leksikografian traditiossa. Virittäjä 122, 4-27. https://doi.org/10.23982/vir.65058

Paloposki, Outi 2007: Suomennoskritiikin alkuvaiheet. H. K. Riıkonen, Urpo Kovala, Pekka KuJAMÄKI ja OUti PALOPOSKI (toim.): Suomennoskirjallisuuden historia 2, 414-424. SKST 1112. Suomalaisen Kirjallisuuden Seura, Helsinki.

2013: Edlundin kustantamo - ensimmäinen suomalainen suurkustantamo. OUTI PALOPOSKI ja H. K. Riıkonen (toim.): Suomennetun tietokirjallisuuden historia 180o-luvulta 20oo-luvulle, 57-65. SKST 1289. Suomalaisen Kirjallisuuden Seura, Helsinki.

Paloposki, Outi - Riıkonen, H. K. 2013: Suomennetun tietokirjallisuuden kritiikistä. Outi PaloposKI ja H. K. Rironen (toim.): Suomennetun tietokirjallisuuden historia 180o-luvulta 20oo-luvulle, 599-616. SKST 1289. Suomalaisen Kirjallisuuden Seura, Helsinki.

Riıkonen, H. K. 2007: Suomennoskritiikin vaiheita 1850-luvulta lähtien. H. K. Riıkonen, Urpo Kovala, Pekкa Kujamäki ja Outi Paloposki (toim.): Suomennoskirjallisuuden historia 2, 425-442. SKST 1112. Suomalaisen Kirjallisuuden Seura, Helsinki.

RompPANEN, BirgitTA 2001: Från målspråk till källspråk: utvecklingen av den finsk-svenska och den enspråkiga finska ordboken. Acta Wasaensis 91. Universitas Wasaensis, Wasa.

SKST $=$ Suomalaisen Kirjallisuuden Seuran Toimituksia.

SulKunen, IrMa 2004: Suomalaisen kirjallisuuden seura 1831-1892. SKST 952. Suomalaisen Kirjallisuuden Seura, Helsinki.

Szalai, Kiti 2006: Tutkimuksen esittelyn retoriikkaa: väitöskirjojen esipuheista ja johdannoista E. N. Setälän fennistiikassa. Pro gradu -tutkielma. Suomen kielen ja kotimaisen kirjallisuuden laitos. Helsingin yliopisto, Helsinki.

VAittinen, TANJA 2010: Kielenohjailua Suomalaisen Kirjallisuuden Seurassa vuosina 1856-1881. SiRKka SaArinen, Kirsti SiItonen ja Tanja Vaittinen (toim.): Sanoista kirjakieliin. Juhlakirja Kaisa Häkkiselle 17. marraskuuta 2010, 129-147. Suomalais-Ugrilaisen Seuran Toimituksia 259. Suomalais-Ugrilainen Seura, Helsinki. 
Minna SEPPÄNEN and Kirsi-Maria Nummila: Foreign language dictionaries published by the Finnish Literature Society in the $19^{\text {th }}$ century: Functions, expectations and reception

In the 19th century, the Finnish Literature Society (SKS) was a major publisher of foreign language dictionaries with Finnish as either the source or target language. This article deals with the publication process of these dictionaries from the points of view of the publisher, the author of the dictionary and the recipient of the publication. The central purpose of the study is to illustrate the goals related to dictionary publication as well as the needs behind these publications. This study examines how such matters are expressed in analysed texts as well as the dialogue between these texts. The research data consist of SKS's minutes, the forewords found in SKS dictionaries and book reviews. The analysed dictionaries were published between 1864 and 1900. This time period is of particular significance due to the development of the Finnish and Finnish-language education and culture.

The minutes describing SKS's operations reveal that, in its internal discussions, the factors seen to be most important reasons for publishing foreign language dictionaries were the increasing needs of the school system and the enrichment of Finnish culture through literature published in the principal languages of the civilised world. SKS aimed to ensure the high quality of its publications through a careful selection of authors and by monitoring the publication process with the help of specially formed committees. However, as seen in the forewords of the dictionaries, we can see that the instructions SKS gave to the authors were not quite thought through and the editorial principles were somewhat unclear. Instructions and objectives were being revised during the publication process, which caused slow progress and inconsistent end results. The goal of trying to meet varying requirements at the same time was not successful, in practice, and the end result was the publication of dictionaries that were not particularly suitable for any target group. The same themes come up in dictionary reviews; however, the reviews also express a clear admiration towards the pioneering spirit of the publications and a sense of national gratitude. Despite their deficiencies, foreign language dictionaries in the 19th century were a significant demonstration of the expressive richness of Finnish and its value as an equal to other languages of the civilised world.

Minna Seppänen mielse@utu.fi Klassilliset kielet ja antiikin kulttuuri 20014 Turun yliopisto
Kirsi-Maria Nummila kirnum@utu.fi Suomen kieli ja suomalaisugrilainen kielentutkimus 20014 Turun yliopisto 